IZA DP No. 4560

Low-Skilled Immigrant Entrepreneurship

Magnus Lofstrom

November 2009 


\title{
Low-Skilled Immigrant Entrepreneurship
}

\author{
Magnus Lofstrom \\ Public Policy Institute of California \\ and IZA
}

Discussion Paper No. 4560

November 2009

\author{
IZA \\ P.O. Box 7240 \\ 53072 Bonn \\ Germany \\ Phone: +49-228-3894-0 \\ Fax: +49-228-3894-180 \\ E-mail: iza@iza.org
}

Any opinions expressed here are those of the author(s) and not those of IZA. Research published in this series may include views on policy, but the institute itself takes no institutional policy positions.

The Institute for the Study of Labor (IZA) in Bonn is a local and virtual international research center and a place of communication between science, politics and business. IZA is an independent nonprofit organization supported by Deutsche Post Foundation. The center is associated with the University of Bonn and offers a stimulating research environment through its international network, workshops and conferences, data service, project support, research visits and doctoral program. IZA engages in (i) original and internationally competitive research in all fields of labor economics, (ii) development of policy concepts, and (iii) dissemination of research results and concepts to the interested public.

IZA Discussion Papers often represent preliminary work and are circulated to encourage discussion. Citation of such a paper should account for its provisional character. A revised version may be available directly from the author. 
IZA Discussion Paper No. 4560

November 2009

\section{ABSTRACT}

\section{Low-Skilled Immigrant Entrepreneurship}

More than half of the foreign born workforce in the U.S. have no schooling beyond high school and about 20 percent of the low-skilled workforce are immigrants. More than 10 percent of these low-skilled immigrants are self-employed. Utilizing longitudinal data from the 1996, 2001 and 2004 Survey of Income and Program Participation panels, this paper analyzes the returns to self-employment among low-skilled immigrants. We compare annual earnings and earnings growth of immigrant entrepreneurs to immigrants in wage/salary employment as well as native born business owners. We find that the returns to low-skilled self-employment among immigrants is higher than it is among natives but also that wage/salary employment is a more financially rewarding option for most low-skilled immigrants. An exception is immigrant men, who are found to have higher earnings growth than immigrants in wage/salary employment and are predicted to reach earnings parity after approximately 10 years in business. We also find that most of the 20 percent male nativeimmigrant earnings gap among low-skilled business owners can be explained primarily by differences in the ethnic composition. Low-skilled female foreign born entrepreneurs are found to have earnings roughly equal to those of self-employed native born women.

JEL Classification: J15, J16, J31, L26

Keywords: immigrants, low-skill, earnings, self-employment, entrepreneurship

Corresponding author:

Magnus Lofstrom

Public Policy Institute of California

500 Washington Street

Suite 600

San Francisco, CA 94111

USA

E-mail: lofstrom@ppic.org 


\section{Introduction}

Immigration has grown steadily over the last decades. Approximately 16 percent of the U.S. workforce is foreign born, a proportion that has more than doubled since its 7 percent share in 1980, shown in Table 1. The composition of immigrants has also changed over this period. Although many immigrants are highly educated and skilled, immigrants also represent a rising large share of the country's low-skilled workers, defined here to be those with no more than a high school diploma. While the immigrant proportion of the college educated workforce increased from 7.1 percent in 1980 to 15.2 percent in 2007, the immigrant share of skilled workers remains roughly equal to the overall proportion of immigrants in the U.S. workforce. However, over this period the share of immigrants in the low-skilled segment of the labor force more than tripled, from 6.7 percent to 20.4 percent, making low-skilled immigrants considerably over-represented among the least educated workers.

Relatively little is known about the labor market performance of this large and growing group of immigrants. Low-skilled workers in general do not fare well in today’s skill intensive economy and their opportunities continue to diminish. Given that individuals in this skill segment of the workforce are more likely to have poor experiences in the labor market, and hence incur greater public expenses, it is particularly important to seek and evaluate their labor market options. From the perspective of immigrant workforce integration, economic contribution and policy, it is also of importance to know specifically how low-skilled immigrants perform in the labor market.

In this paper we focus on the labor market performance of low-skilled self-employed immigrants. Self-employment has been argued to be an important stepping stone for economic assimilation among immigrants (e.g. Cummings, 1980) and self-employed immigrants have been 
found to do better than their wage/salary counterpart (Lofstrom, 2002). It is however unknown whether the relative success among immigrant entrepreneurs hold among the ones with relatively low schooling levels. The research question we seek to answer is whether self-employment is an economically rewarding option for low-skilled immigrants. We address this issue by comparing low-skilled immigrant entrepreneurs to low-skilled immigrants working in the wage/salary sector as well as low-skilled native born business owners. ${ }^{1}$

Self-employment has grown grew substantially over the last few decades, from roughly 9.9 million in 1980 to approximately 17.3 million in $2007 .{ }^{2} \mathrm{~A}$ large number of business owners in the U.S. are low-skilled, 6.9 million, representing about 40 percent of the total number of selfemployed. Importantly, foreign born entrepreneurs play an increasingly important role. This is evident in recent data which show that the entire net increase from 1980 to 2007 of about 1.1 million low-skilled self-employed workers is due to immigrant entrepreneurs (Lofstrom, 2009). In fact, there are fewer native born low-skilled today compared to 1980. This is not due to a decrease in the low-skilled native self-employment rate. In fact, the self-employment rate for both native born low-skilled men and women increased from 1980 to 2007, from 10.1 to 11 percent and 3.9 to 6.1 percent respectively for men and women, shown in Figure 1. The selfemployment rate among the low-skilled foreign born population increased over the same period from 9.8 to 10.5 percent and 4.2 to 10.6 percent for men and women respectively. It is clear from this that self-employment now plays a particularly important role among low-skilled immigrants, especially foreign born women who are now slightly more likely to be self-employed than foreign born men.

\footnotetext{
1 We use the terms self-employed, entrepreneur and business owner synonymously.

2 Author's calculations based on 1980 U.S. Census and the 2007 American Community Survey.
} 
Surprisingly, existing research on low-skilled self-employment, and the performance of lowskilled entrepreneurs, is scant. Exceptions include two papers by Robert Fairlie (2004 and 2005). In these papers he analyzes earnings of disadvantaged entrepreneurs, based on both parental education and the individual's education. Fairlie (2004) studies young less-educated business owners and finds that after a few initial years of slower growth, the average earnings for the selfemployed grow faster over time than the average earnings for wage/salary workers. Fairlie (2005) defines disadvantaged differently and focuses on family background (parents' education). He finds some evidence that disadvantaged self-employed business owners earn more than wage/salary workers from disadvantaged families. Also relevant is Holtz-Eakin, Rosen and Weathers (2000). They analyze possible links between entrepreneurship and earnings mobility and find that low-income self-employed individuals moved ahead in the earnings distribution relative to those who remained in wage/salary work.

This paper contributes to the limited existing research on low-skilled immigrants and lowskilled entrepreneurship in several ways. To our knowledge, this is the first paper to analyze the labor market performance of low-skilled immigrant entrepreneurs in the U.S. We also build on Fairlie's research by separately comparing and analyzing the earnings of low-skilled immigrants and natives. Furthermore, we do not limit our analysis to young workers (ages 22 to 39) but include individuals of all working ages (defined here to be ages 18 to 64).

\section{Comparing Earnings of the Self-Employed and Wage/Salary Workers}

A key objective of the paper is to assess the relative success of immigrant low-skilled entrepreneurs compared to low-skilled wage/salary workers. The measures of success used are 
based on total annual earnings because these outcome measures closely reflect the overall economic well being of individuals.

An important issue to consider when comparing earnings between self-employed and wage/salary workers is the fact that self-employment earnings do not only represent returns to human capital but also returns to financial capital invested in the business. That is, reported selfemployment earnings partially reflect a return to owner investments made in the business while wage/salary earnings do not. In addition to using total annual earnings, we therefore generate two additional earnings measures. The first simply adds to annual earnings annual asset income received from financial capital, i.e. stocks, bonds, real estate and other investments, which is observed for both the self-employed and wage/salary workers. Total annual earnings and capital income is hence an income measure that includes returns to physical and financial capital for self-employed individuals as well as workers in wage/salary employment.

A second alternative approach entails subtracting a portion of the earnings of the selfemployed, which roughly represents owner returns to investments of resources - cash, inventory, equipment, and the like, net of debt -- in their small businesses. Hence, we utilize the reported dollar amount of business equity information available in our data (discussed below) and subtract from annual earnings an amount equal to five percent of this business equity, representing an inflation adjusted real return to a relatively risky investment. Use of the five percent figure is a reflection of the opportunity cost of capital. By assumption, alternative investments into which this business equity dollar amount could be deployed would be expected to earn a five percent real rate of return, roughly equivalent of a nominal return of eight to nine percent. By way of example, an owner reporting a \$50,000 business equity amount, along with annual net profits of $\$ 40,000$, would be assumed to have earned $\$ 2,500$ as a return on her/his business equity 
investment. The balance - profits of $\$ 37,500$ - is attributed to the owner's returns for time spent working in her small business. We refer to this measure as "business equity-adjusted" earnings, which we interpret as an income measure that reflects only returns to human capital for both employed workers and the self-employed.

Although we argue above that the use of a five percent real discount rate is reasonable in this setting, clearly the specific choice of a return to business equity to subtract from the reported annual earnings is ad hoc. The impact of alternative returns is that a higher interest rate leads to lower business equity adjusted earnings while a lower discount rate leads to more favorable comparison for the self-employed (a zero discount rate generates a measure identical to our total annual earnings measure). Lastly, we note that the use of an assumed real return of five percent is similar to Fairlie's (2004) approach and that given the relatively low levels of business equity among low-skilled entrepreneurs, the results are not sensitive to minor changes in the assumed discount rate.

\section{Data}

We use nationally representative individual longitudinal data from the 1996, 2001 and 2004 panels of the U.S. Census Bureau's Survey of Income and Program Participation (SIPP). The SIPP data contain individual demographic information as well as detailed information on labor market activities, business ownership and business characteristics.

The surveys are conducted every four months (representing a "wave") for, depending on the panel, roughly 37,000 to 47,000 U.S. households in each panel. The length of the panel is four years for the 1996 and 2004 panels while the 2001 panel followed individuals for only three years. Importantly given the focus on disadvantaged groups, SIPP panels over-sampled low- 
income households. The data are nationally representative when the provided sampling weights are used. Each wave in the SIPP panels contain both core questions, common to each wave, and topical questions that are not updated in each wave. In addition to the key variables found in the core modules, we use information from two topical modules; immigration (which includes information on country of origin, citizenship status and year of arrival, collected in the $2^{\text {nd }}$ wave in each panel) and assets and liabilities (containing wealth and asset data, including business equity, collected once a year in each panel). ${ }^{3}$

The sample utilized is restricted to low-skilled individuals, men and women, between the ages of 18 and 64 in the survey period who report working at least 15 hours per week. Furthermore, we restrict our sample to individuals for whom immigration status is available and who are observed at least two years during the sample period. The latter restriction is necessary for our earnings growth analysis which relies on an individual fixed effects specification.

We define an individual to be self-employed if she/he reported owning a business in the sample month and usually working at least 15 hours per week in that business. Similarly, individuals are defined to be wage/salary workers, or employees, if she/he does not report owning a business but work at least 15 hours per week in their current job. In addition to these labor market groups, we define additional workforce status groups which are used in lagged form in the empirical earnings models. Individuals reporting owning a business but devoting less than 15 hours per week to it are defined to be part-time self-employed. Part-time wage/salary workers are those not owning a business reporting working for less than 15 hours per week in the reference month. We define a person to be unemployed if they reported experiencing at least one week of unemployment during the month and did not satisfy the criteria for being classified as

\footnotetext{
3 Although the 2004 Panel was originally set to have 12 waves with a full set of topical modules, due to budget constraints, the topical modules were not collected for waves 9-12. Furthermore, the sample was cut by half for this time period.
} 
self-employed or a wage/salary worker. A person is defined to be a welfare recipient if they received Supplemental Security Income (SSI), Aid to Families with Dependent Children (AFDC)/Temporary Assistance for Needy Families (TANF) or food stamps and did not satisfy the definition criteria for self-employment, wage/salary work or unemployment. Lastly, survey respondents who do not meet these criteria are defined to be not in the labor force.

\section{Descriptive Statistics}

We start by examining our annual earnings measures to see how low-skilled entrepreneurs compare to wage/salary earners, shown in Tables 2 and 3. Our data show that low-skilled immigrant entrepreneurs have higher average annual earnings than their counterparts in wage/salary employment and that this also holds among foreign born women. Interestingly, the data show that female U.S. born business owners earn less on average than U.S. born women wage/salary earners.

The magnitude of the differences in average annual earnings depends on the earnings measure. Foreign born male business owners earn on average between 13 (business equity adjusted earnings) and 27 (total annual earnings including capital income) percent more than immigrant men in wage/salary employment. The corresponding average female immigrant selfemployment advantage is somewhat lower, between 7 and 12 percent. Although immigrants earn less on average than their native counterparts, the mean earnings differences above indicate that self-employment is a more financially rewarding option for foreign born entrepreneurs than it is for U.S. born business owners.

A comparison of average earnings can be misleading if the success story among entrepreneurs is one of relatively few very successful business owners (Hamilton, 2000). A 
comparison of earnings by selected percentiles reveals that there is truth to this assertion among the low-skilled. The median annual earnings of low-skilled entrepreneurs -- U.S. and foreign born men and women -- are lower than those of low-skilled employees in the same group. Although the magnitudes of the self-employment disadvantage differ across our three measures, there is no instance in which median earnings are higher among business owners.

The comparison of median earnings differences between wage/salary workers and business owners also indicates lower earnings among immigrants than natives. However, the selfemployment disadvantage is smaller among immigrants, indicating that self-employment is a relatively more rewarding for the foreign born than it is among the U.S. born, a similar conclusion to the one reached by comparing average earnings. We also note that the selfemployment median earnings disadvantages shown in Tables 2 and 3 are very close to the mean earnings differences in the log of annual earnings, the measure used in our empirical approach below. In other words, the log transformation of annual earnings reduces the influence of the highest earning individuals and hence comparisons of mean log annual earnings are more in line with comparisons of median earnings.

The observation that the average earnings are higher among low skilled business owners while the opposite is true when median earnings are compared shows that the most successful entrepreneurs have higher earnings than the most successful workers in the wage/salary sector. We next examine if this is due to relatively few very successful business owners or relatively many entrepreneurs who somewhat outperform wage/salary workers.

The data reveal that among foreign born men, approximately the top half of business owners do as well or outperform the top half of immigrant wage/salary earners. Among natives, the selfemployment earnings advantage is not quite as prevalent. However, we observe that at least the 
top 25 percent low-skilled native born male entrepreneurs have higher earnings than the top 25 percent wage/salary workers. As expected, once self-employment earnings are adjusted for returns to capital invested in the business, self-employment is less rewarding compared to wage/salary work. Nonetheless, both among immigrant and native men, the top 25 percent of low-skilled business owners have higher earnings than the top 25 percent of wage/salary earners.

The top 25 percent female immigrant entrepreneurs have roughly the same or higher earnings than their foreign born counterparts who work in the wage/salary sector. Native born low-skilled business owners are relatively less successful, when compared to their employee counterparts. Table 3 shows that among U.S. born women only the top 10 percent of entrepreneurs outperform the top 10 percent wage/salary workers. In fact, when we adjust earnings for business equity, native born self-employed women throughout the distribution have lower earnings than their employee counterpart.

Immigrant men have lower earnings than native born men. However, the earnings summary statistics in Table 2 indicate that the native-immigrant earnings gap is somewhat smaller among some low-skilled entrepreneurs, namely the ones in the upper end of the earnings distribution. For example, among male entrepreneurs in the top decile, the immigrant-native earnings gap is approximately 10 percent. Among wage/salary earners in the top decile, the gap is twice that, about 21 percent. The data also indicate that both among male low-skilled business owners and wage/salary employees the median native-immigrant earnings gap is about 20 percent.

Female immigrant entrepreneurs appear quite successful when compared to their U.S. born counterpart. A comparison of the mean and median total annual earnings of native and immigrant self-employed women shows no statistically significant earnings difference. Interestingly, a look at the equity adjusted earnings measure reveals that self-employed 
immigrant women have between 8 (median) to 18 (mean) percent higher earnings than lowskilled native self-employed women. This shows that U.S. born female business owners have higher levels of business equity and that these higher levels of equity makes an immigrant-native comparison, not accounting for business equity differences, more favorable to female native entrepreneurs. This is similar to previous research on earnings differences between Latina and non-Hispanic white female business owners (Lofstrom and Bates, forthcoming). The impact of business equity differences between immigrant and native male entrepreneurs is much smaller.

The above descriptive statistics indicate that most low-skilled entrepreneurs have lower earnings than wage/salary workers but also that the economic returns to self-employment are higher for immigrants than natives. Furthermore, compared to low-skilled natives in the same sector, immigrant entrepreneurs are relatively more successful than foreign born wage/salary workers. The latter two observations are important since much of the growth in low-skilled selfemployment is among immigrants and that low-skilled immigrants have higher self-employment rates than low-skilled natives. The relative attractiveness of self-employment is one plausible reason for this.

Some of the observed earnings differences between entrepreneurs and employees may not be attributable to self-employment but may be due to differences in earnings relevant demographic traits (such as education, age, family composition, ethnic composition) or workforce characteristics (such as the number of hours worked, previous period's employment status and workforce experience). A look at differences in the above characteristics between workers in the two sectors, shown in Tables 4 and 5, indicates that the self-employed possess on average more of the attributes associated with higher earnings than wage/salary workers. For example, among immigrants, the self-employed have been in the U.S. longer than foreign born 
wage/salary workers while in general the data show that low-skilled business owners are on average older and work more hours per week than employees. Entrepreneurs are also underrepresented by disadvantaged minority groups such as Hispanics and African-Americans. The extent to how these factors affect earnings and how they contribute to earnings differences across groups are central to our empirical analysis.

\section{Empirical Model Specifications}

Our objective is to assess the relative success of immigrant low-skilled entrepreneurs compared to both low-skilled immigrant wage/salary workers and low-skilled native born business owners. We focus on total annual earnings as our measure of success.

We use ordinary least squares (OLS) to estimate regression models separately for the selfemployed and wage/salary workers by nativity and gender, of the log of total annual earnings. $y_{i t}$, in state $i$ at time $t$. This measure is defined as the log of the sum of wage/salary earnings and selfemployment earnings. The model specification is;

$$
y_{i t}=\mathbf{X}_{i t} \boldsymbol{\beta}+\mathbf{L F S}_{i t-1} \boldsymbol{\delta}+\varepsilon_{i t}
$$

where

$$
\begin{aligned}
& \mathbf{X}_{i t}=\quad \text { Matrix containing individual characteristics such as age, educational } \\
& \text { attainment, marital status, family composition, geographic location, } \\
& \text { ethnicity. For immigrants it also includes controls for years since } \\
& \text { migration and naturalization. }
\end{aligned}
$$

$\mathbf{L F S}_{i t-1}=\quad$ Matrix containing controls for lagged the labor force status, i.e. whether 
the person was observed in wage/salary work, part-time self-employment, part-time self-employment, unemployed, welfare participation or not in the labor force. The matrix also includes controls for number of years at job for wage/salary workers and years in business for the self-employed.

The use of lagged labor force status in our earnings model deserves some justification. These controls are included to reduce omitted variable bias of parameters of interest. Put differently, these controls are intended to purge the data of the impact of previous labor market outcomes or decisions on earnings. Furthermore, since repeated individual observations are not assumed to be independent, all estimates are clustered on individuals.

We also estimate individual fixed effects models to obtain estimates of the impact of years in business or years at current job. In this specification, we do not include lagged labor force status, since it is time invariant for certain sub-groups, including all individuals who stayed in business or remained in the same job for the full sample period. We do however include a control for hours worked per week. It is also possible to include additional controls for variables that may change over time, such as family composition and geographic location. However, the estimated coefficient of these variables are unlikely to represent causal impacts since they are identified through variation in the arguably selective sub-sample for whom these variable values change. Furthermore, including these variables do not appreciably affect the years in business or job parameters. Hence, we opted for presenting the results for the more parsimonious specification.

Lastly, since the analysis is based on a sample in which individuals are not randomly assigned to different labor market states, and that due to no credible instrument is available, we do not model the selection into self-employment. Consequently, the presented estimates are not 
clearly causal. To minimize endogeneity concerns, we go beyond much of the limited existing literature and use model specifications intended to address some of these concerns, such as including controls for work history and controlling for time invariant individual unobserved heterogeneity.

\section{Empirical Results}

The earnings regression results show, as expected, that factors like age, education, experience and hours work have positive impacts on earnings, shown in Tables 6 and 7. Among low-skilled immigrant entrepreneurs, we do not find that time since migration has much of an impact on earnings nor do the data reveal a significant relationship between naturalization and self-employment earnings. ${ }^{4}$ This is contrary to the wage/salary estimates which indicate a positive relationship between these assimilation variables and earnings. Although the minority earnings disadvantages vary across the two sectors, the results show lower earnings among African-Americans and Hispanics.

Above, we pointed out that on average low-skilled business owners are older, work more hours per week than employees and that they have been running their businesses longer than wage/salary employees have been at their current job. We also noted that minorities are underrepresented among business owners. These observations, and the regression estimates, suggest that differences in observable characteristics do not explain the unadjusted lower median and mean log annual earnings of low-skilled business owners. We next turn to an earnings decomposition analysis aimed at shedding further light on factors contributing to the observed

\footnotetext{
4 We explored both linear and quadratic functional forms of years since migration and found similar weak relationships.
} 
group differences in earnings. Before doing so, we note that a look at the differences in the mean of the log of total annual earnings, shown in Table 8, shows that the earnings of self-employed immigrant men is about 4 percent lower than the earnings of immigrant men in wage/salary employment. This is roughly equal to the self-employment earnings disadvantage among lowskilled native born men. Among women, the self-employment log earnings gap is substantially smaller among immigrants (15 percent) than it is among U.S. born women (40 percent).

To specifically analyze how observable earnings related factors affect the earnings differences between wage/salary workers and the self-employed we use an Oaxaca earnings decompositions. To do so, we use the regression estimates in Tables 6 and 7 and the sample means in Tables 4 and 5 to determine how much each observable factor contributes to the mean log earning gaps. This exercise, results presented in Table 8, clearly shows that differences in the observable characteristics do not explain lower earnings among most of the self-employed when compared to wage/salary workers. In fact, the decomposition analysis shows that for all groups the self-employment earnings disadvantages are greater once these factors are considered.

\section{Native-Immigrant Earnings Differences}

Low-skilled immigrant entrepreneurs have lower earnings than native born entrepreneurs. The log annual earnings of foreign born male entrepreneurs are about 20 percent lower than those of native born entrepreneurs. This is also roughly the native-immigrant earnings gap for both men and women in the wage/salary sector. Female immigrant business owners, however, do not have statistically significantly lower earnings than their native counterpart. The role of differences in observable characteristics in explaining earnings differences can also be answered 
by utilizing an Oaxaca earnings decomposition, this time between foreign and U.S. born individuals working in the same sector.

The results, shown in Table 9, show that among self-employed men, the most important factor contributing to the native-immigrant earnings gap is the difference in the ethnic composition of low-skilled business owners. Hispanics make up almost half of low-skilled immigrant entrepreneurs while they represent only about 5 percent of native born self-employed men. This large difference, and the lower earnings among Hispanic business owners, explains essentially the entire native-immigrant self-employment earnings gap. Although of less consequence for the wage/salary native-immigrant earnings gap, the ethnic compositional difference is the most important factor in this sector too. Native-immigrant differences in schooling, hours work per week and experience also contribute to the observed lower earnings among immigrants. Overall, differences in the observable characteristics contribute to about $4 / 5$ of the native-immigrant earnings gap, both among self-employed and wage/salary men.

Although the earnings of self-employed immigrant women is on par with the earnings of native born female business owners, the earnings decomposition analysis suggests that female immigrant entrepreneurs are more likely to reside in states with lower self-employment earnings and that once this is factored in, their predicted earnings is somewhat higher than those of observationally similar native born business owners. The native-immigrant earnings gap among female wage/salary employees can be explained primarily by differences in factors such as experience, education and ethnic composition.

Overall, the data and our analyses indicate that most low-skilled business owners have lower earnings than those of workers in the wage/salary sector. This is reinforced by the observation that entrepreneurs are more likely to possess characteristics, workforce background 
and skills associated with higher earnings. We also find that low-skilled immigrants have lower earnings than low-skilled natives, the exception being that foreign born female business owners do as well as native born self-employed women. However, the analyses so far have not looked at possible differences in earnings growth across both sectors and groups. We next address this issue.

To account for individuals' differences in important unobservable earnings related factors that are assumed to not change over time, such as ability and motivation, we obtain the necessary estimates to identify earnings growth by using individual fixed effects specifications. ${ }^{5}$ This implies that any estimated earnings growth differences between low-skilled entrepreneurs and wage/salary workers are not due to group differences in time invariant individual level unobservable heterogeneity. We use the estimates, presented in Tables 10 and 11, to explore the following earnings scenario of two hypothetical individuals in each group - one who just started her/his own business and the other who instead of entering self-employment started a new job in the wage/salary sector.

The results of this exercise, shown in Figures 2 and 3, provide evidence that in the longrun low-skilled men do relatively well compared to low-skilled employees and especially among foreign born men. Our results show that the earnings of men who just started their business is lower compared to wage/salary workers who just started a new job, approximately eight and two percent lower respectively for native and foreign born men. Interestingly, and similar to Fairlie (2004), the estimates also show that the earnings gap across sectors increases during the immediate following years and peak after about five years at about 14 and 10 percent among U.S. born and immigrant men respectively. However, the results also illustrate that earnings

\footnotetext{
${ }^{5}$ For each group we performed F-tests to determine the appropriate functional form of earnings growth. The best fits appear to be either a second or third degree polynomial.
} 
increase somewhat faster in the subsequent years for self-employed men and are roughly equal after about 10 years among immigrant men and after about 13-14 years for native born men.

Low-skilled female entrepreneurs do not do as well as men when compared to wage/salary earners. We find no evidence that earnings growth is greater among immigrant female business owners than among foreign born women working in wage/salary work. Native born women start out at lower earnings but even in spite of substantial earnings growth there is no evidence that their earnings will reach the levels of wage/salary earners. The differences across sectors are smaller among low-skilled immigrant women but the results show that female immigrant entrepreneurs continue to have lower earnings in the long-run.

Lastly, we note that the earnings growth analysis to some extent overstates the performance of business owners since we have not applied any discounting of the returns to financial capital to our analysis. However, the typically relatively low levels of business equity among low-skilled entrepreneurs suggest that the potential upward bias of their performance is likely to be comparatively minor. Our analysis using our business equity adjusted earnings measure supports the latter but also indicates a relatively less favorable comparison for the selfemployed. 6

\section{Summary and Conclusions}

There are more business owners in the U.S. who have no education beyond high school 6.9 million, than there are self-employed college graduates, 5.6 million. Immigrants play a particularly important role among these less educated entrepreneurs and in fact, the entire net

\footnotetext{
6 The results are not included but are available upon request from the author.
} 
growth in low-skilled self-employment from 1980 to 2007 stems from immigration (Lofstrom, 2009). Furthermore, more than half of the immigrant population in the U.S. are low-skilled (defined here to be individuals with no formal education beyond high school) and are hence particularly likely to face limited labor market opportunities in the increasingly skill intensive U.S. economy. ${ }^{7}$ The ability of the large group of low-skilled immigrants to successfully integrate into the U.S. economy is clearly of importance.

This paper addresses the research question of how well do low-skilled immigrant entrepreneurs do in the U.S. labor market. To answer this question we compare the annual earnings of foreign born business owners to the annual earnings of immigrants in wage/salary employment as well as native born entrepreneurs. The research shows that the answer depends on who low-skilled immigrant entrepreneurs are compared to and the time horizon.

The analysis reveals that although top earning immigrant low-skilled entrepreneurs earn more than top earning immigrant employees, wage/salary employment is a more rewarding option for most low-skilled workers, regardless of gender. This is true in spite of foreign born entrepreneurs possessing more of the characteristics typically associated with higher earnings, such as being older, having greater U.S. labor market experience and working more hours per week than employees. When compared to observationally similar foreign born workers in wage/salary employment, self-employed immigrants have substantially lower earnings.

Our individual fixed effects estimates of earnings growth reveal that the long-run financial gains to low-skilled self-employment are relatively high for immigrant men, who are found to have higher earnings growth than foreign born wage/salary earners. The estimates indicate that after about 10 years in business, their earnings are roughly at the level of

\footnotetext{
7 Author's calculation using the 2007 American Community Survey show that approximately 53 percent of immigrants in the U.S. labor force have no post-secondary education.
} 
wage/salary workers. The catch-up with wage/salary workers appears to be somewhat faster among immigrant men compared to native business owners. However, self-employed immigrant women are not expected to reach the earnings of foreign born women in wage/salary employment in the long-run.

Compared to observationally similar native born male business owners, immigrant entrepreneurs earn slightly less. The observed low-skilled native-immigrant self-employment earnings gap of about 20 percent among men can be explained almost entirely by nativeimmigrant differences in the ethnic composition of business owners, close to 50 percent of lowskilled immigrant entrepreneurs are Hispanic while only about 5 percent of self-employed natives are Hispanic.

Low-skilled female immigrant entrepreneurs do as well as self-employed native females. In fact, once native-immigrant differences in observable factors are accounted for, the results indicate that their earnings are slightly higher, albeit statistically insignificantly so. The earnings growth estimates indicate, however, that the earnings of female native entrepreneurs grow somewhat faster than the earnings of self-employed immigrant women. We do not find evidence that the earnings growth among self-employed immigrant men is greater than that of native born male entrepreneurs.

Although the finding that earnings growth is greater among low-skilled self-employed immigrant men (compared to foreign born workers in wage/salary employment) is consistent with self-employment being a tool that increases low-skilled immigrant economic integration, the estimates also indicate a weaker relationship between increased earnings and years since immigration among foreign born business owners. The lack of strong evidence of relative success among low-skilled immigrant entrepreneurs suggests that previous finding of greater 
labor market assimilation among self-employed immigrants is driven by the relative success of the comparatively higher skilled immigrant entrepreneurs. Lastly but importantly, in spite of the limited evidence of low-skilled entrepreneurial success, the results indicate that the, admittedly low, returns to self-employment are higher among low-skilled immigrants than it is among lowskilled natives.

Overall, the results suggest that self-employment among low-skilled immigrant, and native, workers is not a particularly financially rewarding option. Policies and efforts aimed at increasing the business ownership rates of low-skilled workers are likely to be relatively ineffective ways to increase the economic well being among low-skilled workers. The relative lack of success among low-skilled immigrant entrepreneurs is probably not due to start-up barriers, such as limited availability of start-up capital. Previous research does not find evidence of binding capital constraints for self-employment entry into low-barrier industries, the industries most relevant to low-skilled individuals (Lofstrom and Wang, forthcoming). The difficulties of successfully encouraging low-skilled entrepreneurship is also evident in the body of research which finds that less skilled business owners face significant difficulties staying in business and that micro loan programs aimed at disadvantaged groups are ineffective (e.g., Bates, 1990; Servon and Bates, 1998 and Shane, 2009). Instead, policies aimed at increasing human capital, such as formal schooling, vocational training or English courses, of low-skilled workers are more likely to achieve a policy objective of improving the economic well being of workers in this challenging segment of the skill distribution. 


\section{References}

Bates, Timothy. 1990. "Entrepreneur Human Capital Inputs and Small Business Longevity," Review of Economics and Statistics 72 (4): 551-59.

Bates, Timothy. 1997. Race, Self-Employment \& Upward Mobility: An Illusive American Dream, Washington, D.C.: Woodrow Wilson Center Press and Baltimore: John Hopkins University Press.

Blanchflower, David G. 2004. “Self-Employment: More May Not Be Better”, NBER Working paper No. 10286.

Cummings, Scott. 1980. Self-Help in Urban America: Patterns of Minority Business Enterprise, New York, Kenikart Press.

Fairlie, Robert W. 2005 "Entrepreneurship and Earnings among Young Adults from Disadvantaged Families” Small Business Economics, 25(3): 223-236.

Fairlie, Robert W. 2004 “Earnings Growth among Less-Educated Business Owners” Industrial Relations, 43 (3):634-659.

Hamilton, Barton H. 2000. "Does Entrepreneurship Pay? An Empirical Analysis of the Returns of Self-Employment” The Journal of Political Economy, Vol. 108, No. 3, pp. 604-631

Holtz-Eakin, Douglas, Harvey S. Rosen and Robert Weathers, 2000, 'Horatio Alger Meets the Mobility Tables’, Small Business Economics 14, 243-274.

Lofstrom, Magnus. 2009. "Does Self-Employment Increase the Economic Well-Being of LowSkilled Workers?” IZA Discussion Paper No 4539, October.

Lofstrom, Magnus. 2002. "Labor Market Assimilation and the Self-Employment Decision of Immigrant Entrepreneurs,” Journal of Population Economics, 15:1, pp. 83-114.

Lofstrom, Magnus and Chunbei Wang. Forthcoming. "Mexican-American Self-Employment: A Dynamic Analysis of Business Ownership”, Research in Labor Economics.

Lofstrom, Magnus and Timothy Bates. Forthcoming. "Latina Entrepreneurs”, Small Business Economics.

Servon, Lisa, and Timothy Bates. (1998). "Microenterprise as an Exit Route from Poverty”. Journal of Urban Affairs. 20: 419-41.

Shane, Scott. (2009). "Why Encouraging More People to Become Entrepreneurs is Bad Public Policy” Small Business Economics. 33: 141-9. 
Table 1

\section{Tables}

Trends in the Immigrant Share of the U.S. Population, 1980-2007

\begin{tabular}{ccccc}
\hline & Overall & $\begin{array}{c}\text { High School } \\
\text { or Less }\end{array}$ & $\begin{array}{c}\text { Some } \\
\text { College }\end{array}$ & $\begin{array}{c}\text { College } \\
\text { Graduate }\end{array}$ \\
\hline 1980 & $6.6 \%$ & $6.7 \%$ & $5.8 \%$ & $7.1 \%$ \\
1990 & $9.3 \%$ & $10.8 \%$ & $6.8 \%$ & $9.3 \%$ \\
2000 & $12.5 \%$ & $15.7 \%$ & $8.3 \%$ & $12.5 \%$ \\
2005 & $15.1 \%$ & $19.5 \%$ & $9.7 \%$ & $14.7 \%$ \\
2006 & $15.6 \%$ & $20.0 \%$ & $9.8 \%$ & $15.2 \%$ \\
2007 & $15.7 \%$ & $20.4 \%$ & $9.8 \%$ & $15.2 \%$ \\
\hline
\end{tabular}

Source: 1980, 1990 and 2000 U.S. Census; 2005-2007 American Community Survey. 
Table 2

Summary Statistics, Total Annual Earnings Measures, Low-Skilled Men

\begin{tabular}{lcccccc}
\hline & \multicolumn{5}{c}{ Percentile } \\
& Mean & 10 & 25 & Median & 75 & 90 \\
\cline { 2 - 7 } & \multicolumn{6}{c}{ Immigrants } \\
Self-Employment & 33,451 & 5,655 & 11,785 & 22,352 & 38,669 & 70,055 \\
Wage/Salary & 26,452 & 10,292 & 16,174 & 23,163 & 32,416 & 46,038 \\
Difference (\$) & 6,999 & $-4,637$ & $-4,389$ & -811 & 6,253 & 24,017 \\
Difference (\%) & $26.5 \%$ & $-45.1 \%$ & $-27.1 \%$ & $-3.5 \%$ & $19.3 \%$ & $52.2 \%$ \\
& \multicolumn{7}{c}{ (\%otal Annual Earnings \& Capital Income } \\
Self-Employment & 33,719 & 5,839 & 12,014 & 22,568 & 38,898 & 70,208 \\
Wage/Salary & 26,548 & 10,325 & 16,194 & 23,208 & 32,508 & 46,191 \\
Difference (\$) & 7,172 & $-4,486$ & $-4,180$ & -640 & 6,389 & 24,017 \\
Difference (\%) & $27.0 \%$ & $-43.4 \%$ & $-25.8 \%$ & $-2.8 \%$ & $19.7 \%$ & $52.0 \%$
\end{tabular}

Total Annual Earnings, Business Equity Adjusted

$\begin{array}{lcccccc}\text { Self-Employment } & 30,010 & 3,949 & 10,823 & 20,568 & 36,949 & 63,932 \\ \text { Wage/Salary } & 26,452 & 10,292 & 16,174 & 23,163 & 32,416 & 46,038 \\ \text { Difference (\$) } & 3,558 & -6,343 & -5,351 & -2,596 & 4,533 & 17,894 \\ \text { Difference (\%) } & 13.4 \% & -61.6 \% & -33.1 \% & -11.2 \% & 14.0 \% & 38.9 \%\end{array}$

Natives

\begin{tabular}{lcccccc} 
& \multicolumn{6}{c}{ Natives } \\
\cline { 2 - 7 } & & \multicolumn{7}{c}{ Total Annual Earnings } \\
Self-Employment & 38,177 & 6,537 & 14,083 & 27,475 & 46,028 & 76,640 \\
Wage/Salary & 32,825 & 9,768 & 18,175 & 28,941 & 42,524 & 58,127 \\
$\quad$ Difference (\$) & 5,352 & $-3,231$ & $-4,092$ & $-1,466$ & 3,504 & 18,514 \\
Difference (\%) & $16.3 \%$ & $-33.1 \%$ & $-22.5 \%$ & $-5.1 \%$ & $8.2 \%$ & $31.9 \%$
\end{tabular}

\begin{tabular}{lcccccc} 
& \multicolumn{7}{c}{ Total Annual Earnings \& Capital Income } \\
Self-Employment & 38,768 & 6,781 & 14,527 & 27,948 & 46,702 & 79,358 \\
Wage/Salary & 33,028 & 9,850 & 18,244 & 29,060 & 42,756 & 58,551 \\
$\quad$ Difference (\$) & 5,740 & $-3,069$ & $-3,717$ & $-1,112$ & 3,946 & 20,807 \\
Difference (\%) & $17.4 \%$ & $-31.2 \%$ & $-20.4 \%$ & $-3.8 \%$ & $9.2 \%$ & $35.5 \%$
\end{tabular}

Total Annual Earnings, Business Equity Adjusted

\begin{tabular}{lcccccc} 
Self-Employment & 33,252 & 3,364 & 11,244 & 23,949 & 42,612 & 70,846 \\
Wage/Salary & 32,825 & 9,768 & 18,175 & 28,941 & 42,524 & 58,127 \\
Difference (\$) & 427 & $-6,403$ & $-6,930$ & $-4,993$ & 88 & 12,719 \\
Difference (\%) & $1.3 \%$ & $-65.6 \%$ & $-38.1 \%$ & $-17.3 \%$ & $0.2 \%$ & $21.9 \%$ \\
\hline
\end{tabular}

Source: 1996, 2001 and 2004 Panels of the Survey of Income and Program Participation (SIPP). 
Table 3

Summary Statistics, Total Annual Earnings Measures, Low-Skilled Women

\begin{tabular}{lcccccc}
\hline & \multicolumn{5}{c}{ Percentile } \\
& Mean & 10 & 25 & Median & 75 & 90 \\
\cline { 2 - 7 } & \multicolumn{6}{c}{ Immigrants } \\
Self-Employment & 21,400 & 3,226 & 6,912 & 13,584 & 23,734 & 41,136 \\
Wage/Salary & 19,189 & 5,640 & 10,362 & 16,477 & 24,464 & 35,045 \\
Difference (\$) & 2,211 & $-2,414$ & $-3,450$ & $-2,892$ & -730 & 6,091 \\
Difference (\%) & $11.5 \%$ & $-42.8 \%$ & $-33.3 \%$ & $-17.6 \%$ & $-3.0 \%$ & $17.4 \%$ \\
& & \multicolumn{7}{c}{ Total Annual Earnings \& Capital Income } \\
Self-Employment & 21,638 & 3,435 & 7,032 & 13,728 & 23,813 & 41,699 \\
Wage/Salary & 19,343 & 5,722 & 10,384 & 16,555 & 24,641 & 35,528 \\
Difference (\$) & 2,295 & $-2,287$ & $-3,352$ & $-2,827$ & -828 & 6,171 \\
Difference (\%) & $11.9 \%$ & $-40.0 \%$ & $-32.3 \%$ & $-17.1 \%$ & $-3.4 \%$ & $17.4 \%$
\end{tabular}

Total Annual Earnings, Business Equity Adjusted

$\begin{array}{lcccccc}\text { Self-Employment } & 20,579 & 2,524 & 5,948 & 12,879 & 22,653 & 40,052 \\ \text { Wage/Salary } & 19,189 & 5,640 & 10,362 & 16,477 & 24,464 & 35,045 \\ \text { Difference (\$) } & 1,390 & -3,115 & -4,414 & -3,598 & -1,812 & 5,007 \\ \text { Difference (\%) } & 7.2 \% & -55.2 \% & -42.6 \% & -21.8 \% & -7.4 \% & 14.3 \%\end{array}$

Natives

\begin{tabular}{|c|c|c|c|c|c|c|}
\hline \multirow[b]{3}{*}{ Self-Employment } & \multicolumn{6}{|c|}{ Natives } \\
\hline & \multicolumn{6}{|c|}{ Total Annual Earnings } \\
\hline & 21,092 & 2,897 & 6,574 & 13,824 & 26,146 & 45,298 \\
\hline Wage/Salary & 22,287 & 6,098 & 11,577 & 19,492 & 29,203 & 40,212 \\
\hline Difference (\$) & $-1,195$ & $-3,201$ & $-5,003$ & $-5,668$ & $-3,057$ & 5,086 \\
\hline Difference (\%) & $-5.4 \%$ & $-52.5 \%$ & $-43.2 \%$ & $-29.1 \%$ & $-10.5 \%$ & $12.6 \%$ \\
\hline
\end{tabular}

\begin{tabular}{lcccccc} 
& \multicolumn{7}{c}{ Total Annual Earnings \& Capital Income } \\
Self-Employment & 21,764 & 3,035 & 7,024 & 14,475 & 26,997 & 46,889 \\
Wage/Salary & 22,509 & 6,217 & 11,677 & 19,678 & 29,530 & 40,552 \\
$\quad$ Difference (\$) & -745 & $-3,183$ & $-4,653$ & $-5,203$ & $-2,533$ & 6,337 \\
Difference (\%) & $-3.3 \%$ & $-51.2 \%$ & $-39.8 \%$ & $-26.4 \%$ & $-8.6 \%$ & $15.6 \%$
\end{tabular}

Total Annual Earnings, Business Equity Adjusted

\begin{tabular}{ccccccc} 
Self-Employment & 17,437 & 1,264 & 4,925 & 11,961 & 22,735 & 39,535 \\
Wage/Salary & 22,287 & 6,098 & 11,577 & 19,492 & 29,203 & 40,212 \\
Difference (\$) & $-4,850$ & $-4,834$ & $-6,653$ & $-7,531$ & $-6,468$ & -677 \\
Difference (\%) & $-21.8 \%$ & $-79.3 \%$ & $-57.5 \%$ & $-38.6 \%$ & $-22.1 \%$ & $-1.7 \%$ \\
\hline
\end{tabular}

Source: 1996, 2001 and 2004 Panels of the Survey of Income and Program Participation (SIPP). 


\section{Table 4}

Descriptive Statistics, Low-Skilled Men

\begin{tabular}{|c|c|c|c|c|}
\hline \multirow[b]{2}{*}{ Variable } & \multicolumn{2}{|c|}{ Immigrants } & \multicolumn{2}{|c|}{ Natives } \\
\hline & $\begin{array}{c}\text { Self- } \\
\text { Employed }\end{array}$ & $\begin{array}{l}\text { Wage/ } \\
\text { Salary } \\
\end{array}$ & $\begin{array}{c}\text { Self- } \\
\text { Employed }\end{array}$ & $\begin{array}{l}\text { Wage/ } \\
\text { Salary } \\
\end{array}$ \\
\hline Years of Schooling & 10.32 & 10.05 & 11.51 & 11.58 \\
\hline Less than High School & $32.1 \%$ & $38.7 \%$ & $17.0 \%$ & $16.0 \%$ \\
\hline High School Graduate & $67.9 \%$ & $61.3 \%$ & $83.0 \%$ & $84.0 \%$ \\
\hline Age & 42.54 & 36.68 & 44.04 & 38.17 \\
\hline Youngest Child Younger Than 1 & $17.3 \%$ & $18.5 \%$ & $11.3 \%$ & $10.8 \%$ \\
\hline Youngest Child Aged 1 & $5.8 \%$ & $5.4 \%$ & $3.0 \%$ & $3.1 \%$ \\
\hline Youngest Child Between Ages 2 and 3 & $7.8 \%$ & $7.6 \%$ & $4.4 \%$ & $5.1 \%$ \\
\hline Youngest Child Between Ages 4 and 5 & $6.9 \%$ & $5.9 \%$ & $4.3 \%$ & $4.0 \%$ \\
\hline Youngest Child Between Ages 6 and 12 & $13.4 \%$ & $15.6 \%$ & $15.2 \%$ & $14.6 \%$ \\
\hline Youngest Child Teenager & $4.8 \%$ & $4.6 \%$ & $5.5 \%$ & $6.1 \%$ \\
\hline Single & $28.7 \%$ & $43.8 \%$ & $31.0 \%$ & $46.5 \%$ \\
\hline Persons in Household & 3.95 & 4.04 & 3.18 & 3.23 \\
\hline Metropolitan Resident & $83.4 \%$ & $86.1 \%$ & $64.1 \%$ & $72.0 \%$ \\
\hline White & $34.9 \%$ & $26.0 \%$ & $87.1 \%$ & $74.8 \%$ \\
\hline Hispanic & $48.8 \%$ & $59.6 \%$ & $5.5 \%$ & $10.4 \%$ \\
\hline African-American & $4.3 \%$ & $6.7 \%$ & $5.6 \%$ & $12.7 \%$ \\
\hline Asian & $8.6 \%$ & $5.2 \%$ & $0.6 \%$ & $0.4 \%$ \\
\hline Other Ethnic Group & $3.5 \%$ & $2.5 \%$ & $1.2 \%$ & $1.7 \%$ \\
\hline Years Since Migration & 19.2 & 16.4 & & \\
\hline Not Naturalized Citizen & $44.4 \%$ & $51.0 \%$ & & \\
\hline Years at Job & 7.64 & 5.43 & 11.02 & 7.75 \\
\hline Typical Weekly Hours Worked & 48.43 & 42.83 & 50.37 & 43.5 \\
\hline \multicolumn{5}{|l|}{ Previous Year's Labor Force Status } \\
\hline Wage/Salary & $14.5 \%$ & $87.5 \%$ & $9.1 \%$ & $87.6 \%$ \\
\hline Self-Employed & $76.0 \%$ & $1.3 \%$ & $83.3 \%$ & $1.3 \%$ \\
\hline Wage/Salary, Less than 15 Hours/Week & & $0.5 \%$ & $0.1 \%$ & $0.8 \%$ \\
\hline Self-Employed, Less than 15 Hours/Week & $1.9 \%$ & $0.2 \%$ & $3.3 \%$ & $0.3 \%$ \\
\hline Unemployed & $1.6 \%$ & $3.8 \%$ & $1.2 \%$ & $3.7 \%$ \\
\hline Welfare & $0.7 \%$ & $1.3 \%$ & $0.5 \%$ & $1.1 \%$ \\
\hline Not in the Labor Force & $5.3 \%$ & $5.3 \%$ & $2.6 \%$ & $5.2 \%$ \\
\hline Number of Observations & 1,198 & 9,063 & 4,466 & 29,394 \\
\hline
\end{tabular}

Source: 1996, 2001 and 2004 Panels of the Survey of Income and Program Participation (SIPP). 


\section{Table 5}

Descriptive Statistics, Low-Skilled Women

\begin{tabular}{|c|c|c|c|c|}
\hline \multirow[b]{2}{*}{ Variable } & \multicolumn{2}{|c|}{ Immigrants } & \multicolumn{2}{|c|}{ Natives } \\
\hline & $\begin{array}{c}\text { Self- } \\
\text { Employed }\end{array}$ & $\begin{array}{l}\text { Wage/ } \\
\text { Salary } \\
\end{array}$ & $\begin{array}{c}\text { Self- } \\
\text { Employed }\end{array}$ & $\begin{array}{l}\text { Wage/ } \\
\text { Salary } \\
\end{array}$ \\
\hline Years of Schooling & 10.09 & 10.4 & 11.59 & 11.69 \\
\hline Less than High School & $33.6 \%$ & $32.4 \%$ & $15.3 \%$ & $13.3 \%$ \\
\hline High School Graduate & $66.4 \%$ & $67.6 \%$ & $84.7 \%$ & $86.7 \%$ \\
\hline Age & 43.45 & 39.32 & 44.77 & 40.1 \\
\hline Youngest Child Younger Than 1 & $10.4 \%$ & $13.7 \%$ & $10.9 \%$ & $10.1 \%$ \\
\hline Youngest Child Aged 1 & $5.0 \%$ & $5.6 \%$ & $3.3 \%$ & $3.8 \%$ \\
\hline Youngest Child Between Ages 2 and 3 & $9.3 \%$ & $7.4 \%$ & $4.6 \%$ & $5.8 \%$ \\
\hline Youngest Child Between Ages 4 and 5 & $6.8 \%$ & $7.0 \%$ & $4.7 \%$ & $5.2 \%$ \\
\hline Youngest Child Between Ages 6 and 12 & $19.0 \%$ & $21.0 \%$ & $18.2 \%$ & $17.3 \%$ \\
\hline Youngest Child Teenager & $7.4 \%$ & $5.8 \%$ & $6.4 \%$ & $6.6 \%$ \\
\hline Single & $36.6 \%$ & $45.1 \%$ & $28.6 \%$ & $47.9 \%$ \\
\hline Persons in Household & 3.83 & 3.88 & 3.15 & 3.17 \\
\hline Metropolitan Resident & $93.0 \%$ & $87.2 \%$ & $70.3 \%$ & $73.9 \%$ \\
\hline White & $27.0 \%$ & $28.9 \%$ & $83.9 \%$ & $73.1 \%$ \\
\hline Hispanic & $49.1 \%$ & $48.6 \%$ & $6.0 \%$ & $8.8 \%$ \\
\hline African-American & $6.1 \%$ & $9.6 \%$ & $7.7 \%$ & $15.7 \%$ \\
\hline Asian & $14.1 \%$ & $9.5 \%$ & $0.3 \%$ & $0.4 \%$ \\
\hline Other Ethnic Group & $3.7 \%$ & $3.5 \%$ & $2.1 \%$ & $1.9 \%$ \\
\hline Years Since Migration & 18.9 & 17.9 & & \\
\hline Not Naturalized Citizen & $49.2 \%$ & $45.4 \%$ & & \\
\hline Years at Job & 6.49 & 4.89 & 8.06 & 6.85 \\
\hline Typical Weekly Hours Worked & 41.1 & 38.58 & 43.08 & 38.49 \\
\hline \multicolumn{5}{|l|}{ Previous Year's Labor Force Status } \\
\hline Wage/Salary & $9.3 \%$ & $80.0 \%$ & $9.9 \%$ & $85.1 \%$ \\
\hline Self-Employed & $73.7 \%$ & $0.9 \%$ & $74.3 \%$ & $0.7 \%$ \\
\hline Wage/Salary, Less than 15 Hours/Week & $0.3 \%$ & $1.6 \%$ & $0.5 \%$ & $1.6 \%$ \\
\hline Self-Employed, Less than 15 Hours/Week & $2.8 \%$ & $0.2 \%$ & $5.6 \%$ & $0.3 \%$ \\
\hline Unemployed & $2.3 \%$ & $3.9 \%$ & $1.8 \%$ & $3.0 \%$ \\
\hline Welfare & $2.2 \%$ & $3.3 \%$ & $1.4 \%$ & $2.8 \%$ \\
\hline Not in the Labor Force & $9.4 \%$ & $10.2 \%$ & $6.5 \%$ & $6.5 \%$ \\
\hline Number of Observations & 589 & 6,368 & 1,922 & 26,818 \\
\hline
\end{tabular}

Source: 1996, 2001 and 2004 Panels of the Survey of Income and Program Participation (SIPP). 


\section{Table 6}

Ordinary Least Squares, Log of Total Annual Earnings, Men.

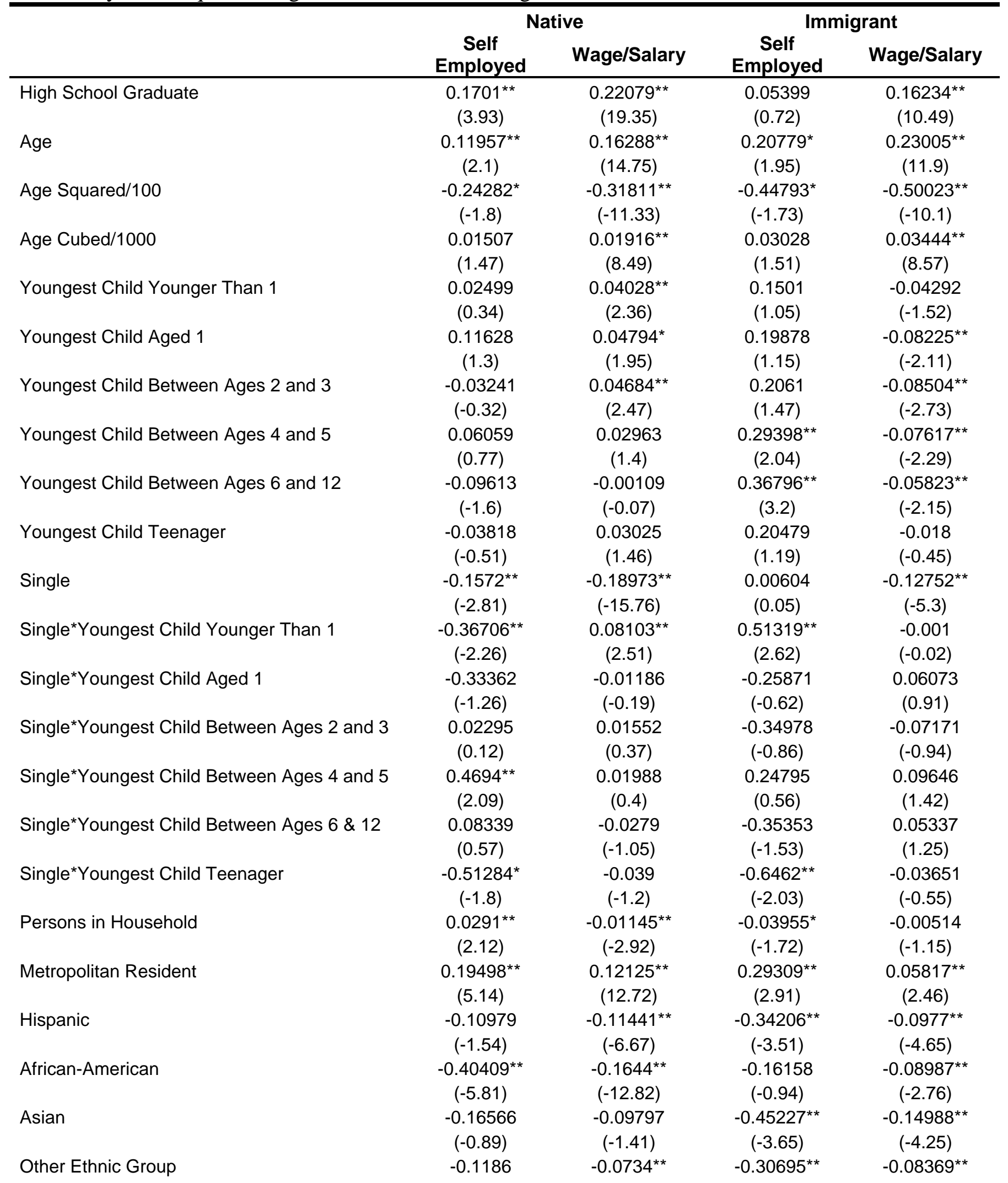




\begin{tabular}{|c|c|c|c|c|}
\hline & $(-0.96)$ & $(-2.24)$ & $(-2.27)$ & $(-2.09)$ \\
\hline Typical Weekly Hours Worked & $\begin{array}{c}0.01096^{\star \star} \\
(14.36)\end{array}$ & $\begin{array}{c}0.01332^{\star *} \\
(33.12)\end{array}$ & $\begin{array}{c}0.01488^{* *} \\
(9.23)\end{array}$ & $\begin{array}{c}0.01268^{\star \star} \\
(17)\end{array}$ \\
\hline Years at Job & $\begin{array}{c}0.04812^{* *} \\
(4.23)\end{array}$ & $\begin{array}{c}0.05544^{* *} \\
(19.65)\end{array}$ & $\begin{array}{c}0.05998^{\star *} \\
(2.67)\end{array}$ & $\begin{array}{c}0.06776^{* *} \\
(10.07)\end{array}$ \\
\hline Years at Job Squared/100 & $\begin{array}{c}-0.21885^{\star *} \\
(-2.97)\end{array}$ & $\begin{array}{c}-0.24186^{\star *} \\
(-12.73)\end{array}$ & $\begin{array}{c}-0.27014^{*} \\
(-1.84)\end{array}$ & $\begin{array}{c}-0.37981^{\text {** }} \\
(-6.04)\end{array}$ \\
\hline Years at Job Cubed/1000 & $\begin{array}{c}0.02808^{\star *} \\
(2.29)\end{array}$ & $\begin{array}{c}0.03587^{\star \star} \\
(10.32)\end{array}$ & $\begin{array}{c}0.03615 \\
(1.41)\end{array}$ & $\begin{array}{c}0.06613^{\star *} \\
(4.5)\end{array}$ \\
\hline Years Since Migration & & & $\begin{array}{c}0.00555 \\
(1.02)\end{array}$ & $\begin{array}{c}0.00304^{\star *} \\
(2.81)\end{array}$ \\
\hline Years Since Migration Squared & & & $\begin{array}{c}0.04915 \\
(0.3)\end{array}$ & $\begin{array}{c}0.04211^{*} \\
(1.67)\end{array}$ \\
\hline Years Since Migration Cubed & & & $\begin{array}{c}0.01325 \\
(0.11)\end{array}$ & $\begin{array}{c}-0.03102 \\
(-1.11)\end{array}$ \\
\hline Not Naturalized Citizen & & & $\begin{array}{c}0.07855 \\
(0.97)\end{array}$ & $\begin{array}{c}-0.05315^{\star \star} \\
(-3.1)\end{array}$ \\
\hline \multicolumn{5}{|l|}{ Previous Year's Labor Force Status } \\
\hline Wage/Salary & $\begin{array}{c}0.49227^{\star *} \\
(4.71)\end{array}$ & $\begin{array}{c}0.63193^{\star *} \\
(26.03)\end{array}$ & $\begin{array}{c}0.48596^{\star \star} \\
(2.23)\end{array}$ & $\begin{array}{c}0.4941^{\star *} \\
(11.97)\end{array}$ \\
\hline Self-Employed & $\begin{array}{c}0.47177^{\star *} \\
(4.78)\end{array}$ & $\begin{array}{c}0.47563^{* *} \\
(9.28)\end{array}$ & $\begin{array}{c}0.49752^{\star *} \\
(2.28)\end{array}$ & $\begin{array}{c}0.44972^{\star *} \\
(6.53)\end{array}$ \\
\hline Wage/Salary, Less than 15 Hours/Week & $\begin{array}{c}-1.55668^{\star *} \\
(-2.81)\end{array}$ & $\begin{array}{c}0.07941 \\
(1.4)\end{array}$ & & $\begin{array}{c}-0.02763 \\
(-0.26)\end{array}$ \\
\hline Self-Employed, Less than 15 Hours/Week & $\begin{array}{l}0.2267 \\
(1.57)\end{array}$ & $\begin{array}{c}0.55095^{\star *} \\
(7.6)\end{array}$ & $\begin{array}{c}0.16068 \\
(0.52)\end{array}$ & $\begin{array}{c}0.30062^{\star \star} \\
(2.11)\end{array}$ \\
\hline Unemployed & $\begin{array}{c}-0.20397 \\
(-1.1)\end{array}$ & $\begin{array}{c}0.14304^{\star *} \\
(3.55)\end{array}$ & $\begin{array}{c}-0.29606 \\
(-0.96)\end{array}$ & $\begin{array}{c}0.11788^{\star *} \\
(1.98)\end{array}$ \\
\hline Welfare & $\begin{array}{c}-0.36611 \\
(-1.36)\end{array}$ & $\begin{array}{c}-0.40321^{* *} \\
(-4.48)\end{array}$ & $\begin{array}{c}-0.76336^{*} \\
(-1.77)\end{array}$ & $\begin{array}{c}-0.13799 \\
(-1.49)\end{array}$ \\
\hline Constant & $\begin{array}{c}6.687^{\star *} \\
(8.73)\end{array}$ & $\begin{array}{c}6.14298^{\star *} \\
(45.71)\end{array}$ & $\begin{array}{c}5.21897^{\star \star} \\
(3.68)\end{array}$ & $\begin{array}{c}5.56464^{\star *} \\
(24.06)\end{array}$ \\
\hline $\mathrm{R}$ squared & 0.1548 & 0.4707 & 0.2664 & 0.4231 \\
\hline Number of Observations & 4,620 & 30,377 & 1,224 & 9,466 \\
\hline
\end{tabular}

Note: t-statistics are shown in parentheses. Standard errors are adjusted for individual repeated observations, i.e. clusters. All models include state fixed effects. 
Table 7

Ordinary Least Squares, Log of Total Annual Earnings, Women.

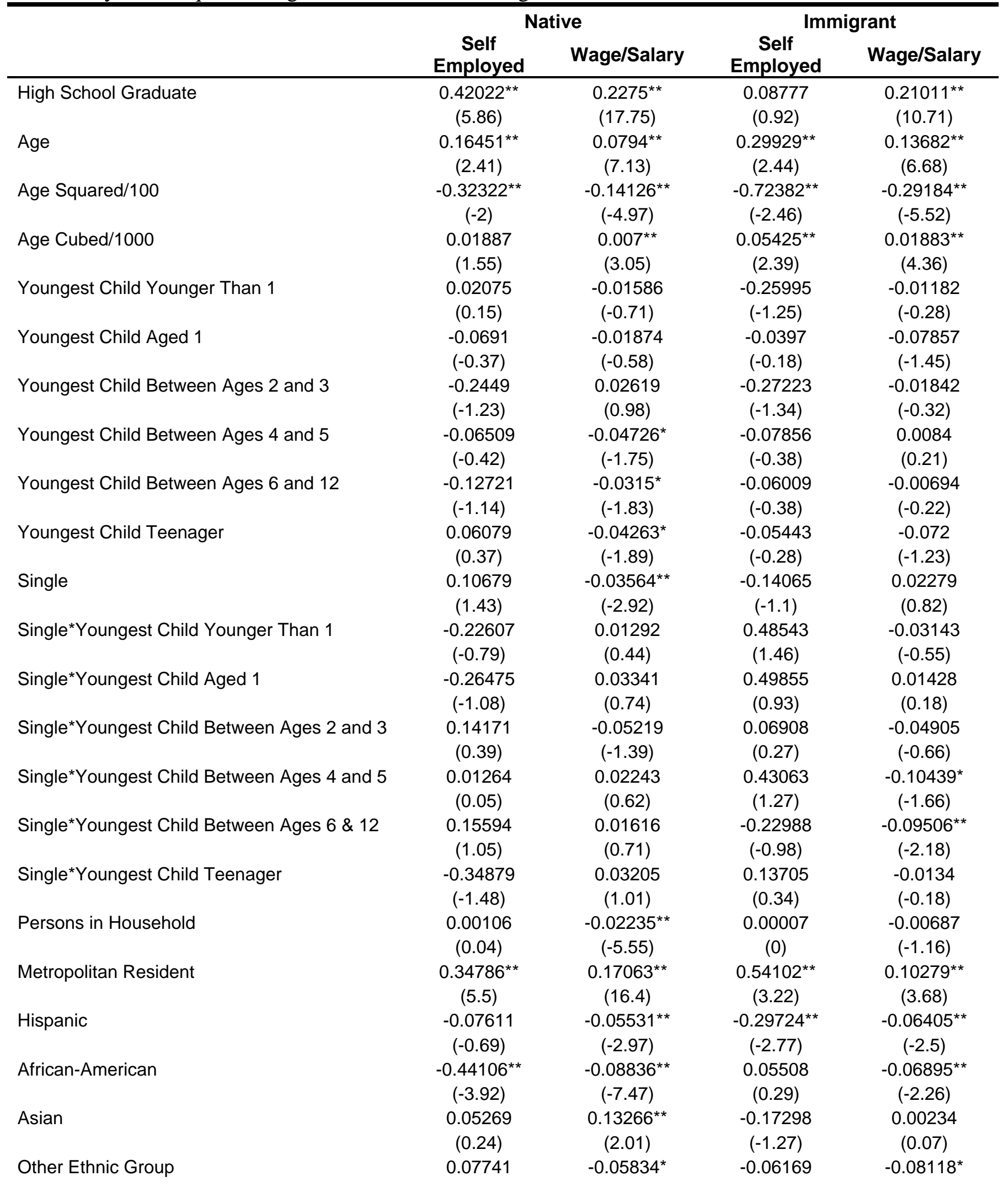




\begin{tabular}{|c|c|c|c|c|}
\hline & $(0.5)$ & $(-1.74)$ & $(-0.35)$ & $(-1.68)$ \\
\hline Typical Weekly Hours Worked & $\begin{array}{c}0.01052^{* *} \\
(7.28)\end{array}$ & $\begin{array}{c}0.02117^{* *} \\
(44.74)\end{array}$ & $\begin{array}{c}0.01334^{* *} \\
(5.38)\end{array}$ & $\begin{array}{c}0.01956^{* *} \\
(21.49)\end{array}$ \\
\hline Years at Job & $\begin{array}{c}0.04933^{\star \star} \\
(2.5)\end{array}$ & $\begin{array}{c}0.07787^{\star \star} \\
(24.21)\end{array}$ & $\begin{array}{c}0.0527^{\star} \\
(1.73)\end{array}$ & $\begin{array}{c}0.0994^{\star \star} \\
(14.27)\end{array}$ \\
\hline Years at Job Squared/100 & $\begin{array}{c}-0.19778 \\
(-1.55)\end{array}$ & $\begin{array}{c}-0.32152^{\star *} \\
(-13.58)\end{array}$ & $\begin{array}{c}-0.16324 \\
(-0.74)\end{array}$ & $\begin{array}{c}-0.49835^{\star \star} \\
(-8.89)\end{array}$ \\
\hline Years at Job Cubed/1000 & $\begin{array}{l}0.0245 \\
(1.11)\end{array}$ & $\begin{array}{c}0.04398^{\star *} \\
(9.23)\end{array}$ & $\begin{array}{c}0.00838 \\
(0.21)\end{array}$ & $\begin{array}{c}0.07915^{\star *} \\
\quad(6.6)\end{array}$ \\
\hline Years Since Migration & & & $\begin{array}{c}0.00511 \\
(0.82)\end{array}$ & $\begin{array}{c}0.00296^{* *} \\
(2.35)\end{array}$ \\
\hline Years Since Migration Squared & & & $\begin{array}{c}-0.08642 \\
(-0.54)\end{array}$ & $\begin{array}{c}0.01628 \\
(0.45)\end{array}$ \\
\hline Years Since Migration Cubed & & & $\begin{array}{c}-0.34334^{\star \star} \\
(-2.7)\end{array}$ & $\begin{array}{c}-0.00951 \\
(-0.36)\end{array}$ \\
\hline Not Naturalized Citizen & & & $\begin{array}{c}-0.09385 \\
(-0.94)\end{array}$ & $\begin{array}{c}-0.04835^{\star \star} \\
(-2.28)\end{array}$ \\
\hline \multicolumn{5}{|l|}{ Previous Year's Labor Force Status } \\
\hline Wage/Salary & $\begin{array}{c}0.87241^{\star \star} \\
(6.17)\end{array}$ & $\begin{array}{c}0.70602^{\star *} \\
(27.35)\end{array}$ & $\begin{array}{c}0.92871^{\star *} \\
(4.52)\end{array}$ & $\begin{array}{l}0.578^{\star \star} \\
(16.95)\end{array}$ \\
\hline Self-Employed & $\begin{array}{c}0.88404^{\star *} \\
(6.8)\end{array}$ & $\begin{array}{l}0.54^{\star *} \\
(7.71)\end{array}$ & $\begin{array}{c}1.09228^{\star *} \\
(6.28)\end{array}$ & $\begin{array}{c}0.33951^{* *} \\
(2.54)\end{array}$ \\
\hline Wage/Salary, Less than 15 Hours/Week & $\begin{array}{c}0.42041 \\
(1.37)\end{array}$ & $\begin{array}{c}0.13781^{\star *} \\
(3.24)\end{array}$ & $\begin{array}{c}-0.64615 \\
(-0.96)\end{array}$ & $\begin{array}{c}0.13505^{\star} \\
(1.78)\end{array}$ \\
\hline Self-Employed, Less than 15 Hours/Week & $\begin{array}{c}0.62188^{\star \star} \\
(3.39)\end{array}$ & $\begin{array}{c}0.51075^{\star *} \\
(6.92)\end{array}$ & $\begin{array}{c}0.93818^{\star *} \\
(3.41)\end{array}$ & $\begin{array}{c}0.20752 \\
(0.7)\end{array}$ \\
\hline Unemployed & $\begin{array}{c}0.10547 \\
(0.37)\end{array}$ & $\begin{array}{c}0.22097^{* *} \\
(5.52)\end{array}$ & $\begin{array}{c}0.56595^{\star} \\
(1.66)\end{array}$ & $\begin{array}{c}0.08841 \\
(1.44)\end{array}$ \\
\hline Welfare & $\begin{array}{c}-0.39265 \\
(-1.22)\end{array}$ & $\begin{array}{c}-0.20739^{\star *} \\
(-4.69)\end{array}$ & $\begin{array}{c}0.14547 \\
(0.4)\end{array}$ & $\begin{array}{c}-0.11906^{*} \\
(-1.78)\end{array}$ \\
\hline Constant & $\begin{array}{c}4.86301^{\star *} \\
(5.27)\end{array}$ & $\begin{array}{c}6.52221^{\star *} \\
(49.69)\end{array}$ & $\begin{array}{c}3.57399^{\star *} \\
(2.25)\end{array}$ & $\begin{array}{c}5.99562^{\star *} \\
(24.67)\end{array}$ \\
\hline R squared & 0.2191 & 0.4813 & 0.3999 & 0.4968 \\
\hline Number of Observations & 2,011 & 27,888 & 604 & 6,807 \\
\hline
\end{tabular}

Note: t-statistics are shown in parentheses. Standard errors are adjusted for individual repeated observations, i.e. clusters. All models include state fixed effects. 


\section{Table 8}

Oaxaca Decomposition of Log Total Annual Earnings Mean Differences between Low-Skilled Self-Employed and Wage/Salary Employers.

\begin{tabular}{lcccc}
\hline & \multicolumn{2}{c}{ Men } & \multicolumn{2}{c}{ Women } \\
& Immigrants & Natives & Immigrants & Natives \\
\hline $\begin{array}{l}\text { Observed Mean Wage/Salary Advantage } \\
\quad \text { Total Annual Earnings }\end{array}$ & & & & \\
$\quad$ & $4.3 \%$ & $3.8 \%$ & $15.0 \%$ & $39.4 \%$ \\
$\quad$ & & & \\
Contribution due to & & & & \\
$\quad$ Education & $-0.4 \%$ & $-0.01 \%$ & $-0.1 \%$ & $0.3 \%$ \\
Age & $-5.7 \%$ & $-3.3 \%$ & $-3.1 \%$ & $-3.0 \%$ \\
Household Composition & $-2.5 \%$ & $-3.7 \%$ & $-0.9 \%$ & $0.9 \%$ \\
Geographic Location & $2.2 \%$ & $1.7 \%$ & $-5.6 \%$ & $0.5 \%$ \\
$\quad$ Ethnic Composition & $-1.7 \%$ & $-3.4 \%$ & $1.5 \%$ & $-3.6 \%$ \\
Hours Work per Week & $-8.5 \%$ & $-7.7 \%$ & $0.5 \%$ & $-4.9 \%$ \\
Years in Business/Job & $-4.5 \%$ & $-4.4 \%$ & $-0.6 \%$ & $-3.7 \%$ \\
Previous Labor Market Status & $-3.9 \%$ & $-3.3 \%$ & $-4.3 \%$ & $-3.3 \%$ \\
Year Effects & $-0.3 \%$ & $-0.01 \%$ & $-5.0 \%$ & $-0.3 \%$ \\
$\quad$ Not Naturalized & $0.5 \%$ & N/A & $-18.4 \%$ & N/A \\
Years in the U.S. & $-0.8 \%$ & N/A & $-0.5 \%$ & N/A \\
& & & & \\
Total Due to Characteristics & $-25.7 \%$ & $-24.1 \%$ & $-36.5 \%$ & $-17.2 \%$ \\
\hline
\end{tabular}

Note: Based on sample means and regressions results presented in Tables 3-4 and Tables 5-6. 


\section{Table 9}

Oaxaca Decomposition of Log Total Annual Earnings Mean Differences between Low-Skilled Natives and Immigrants, by Sector.

\begin{tabular}{lcccc}
\hline & \multicolumn{2}{c}{ Self-Employed } & \multicolumn{2}{c}{ Wage/Salary } \\
& Men & Women & Men & Women \\
\hline Observed Annual Earnings Difference, & & & & \\
Natives - Immigrants & $20.3 \%$ & $2.2 \%$ & $19.6 \%$ & $18.4 \%$ \\
& & & & \\
Contribution due to & & & & \\
$\quad$ Education & $0.8 \%$ & $-7.5 \%$ & $4.0 \%$ & $4.7 \%$ \\
$\quad$ Age & $-0.8 \%$ & $3.2 \%$ & $-0.3 \%$ & $-0.3 \%$ \\
$\quad$ Household Composition & $-0.5 \%$ & $-0.5 \%$ & $1.2 \%$ & $1.0 \%$ \\
$\quad-11.7 \%$ & $11.3 \%$ & $0.7 \%$ & $-0.9 \%$ \\
$\quad$ Geographic Location & $19.6 \%$ & $-1.7 \%$ & $5.1 \%$ & $3.1 \%$ \\
$\quad$ Ethnic Composition & $3.2 \%$ & $-1.8 \%$ & $1.0 \%$ & $0.6 \%$ \\
$\quad$ Hours Work per Week & $4.4 \%$ & $-2.5 \%$ & $3.2 \%$ & $5.6 \%$ \\
$\quad$ Years in Business/Job & $1.9 \%$ & $-3.4 \%$ & $0.5 \%$ & $4.1 \%$ \\
$\quad$ Previous Labor Market Status & $0.8 \%$ & $1.0 \%$ & $0.7 \%$ & $0.5 \%$ \\
$\quad$ Year Effects & & & & \\
$\quad$ Total Due to Characteristics & $16.1 \%$ & $-2.8 \%$ & $17.2 \%$ & $19.8 \%$ \\
$\quad$ Proportion of Observed Difference & $79.5 \%$ & $-124.0 \%$ & $87.5 \%$ & $107.4 \%$ \\
\hline
\end{tabular}

Note: Based on sample means and regressions results presented in Tables 3-4 and regression estimates using the specifications in Tables 5-6 with the exception that controls for years since migration and not-naturalized are excluded for immigrants. 
Table 10

Fixed Effects Log Annual Earnings Models, Men

\begin{tabular}{lcccc}
\hline & \multicolumn{2}{c}{ Native } & \multicolumn{2}{c}{ Immigrant } \\
& $\begin{array}{c}\text { Self } \\
\text { Employed }\end{array}$ & Wage/Salary & $\begin{array}{c}\text { Self } \\
\text { Employed }\end{array}$ & Wage/Salary \\
\hline Typical Weekly Hours Worked & $0.0059^{* *}$ & $0.0055^{* *}$ & $0.0098^{* *}$ & $0.0066^{* *}$ \\
& $(4.27)$ & $(13.99)$ & $(2.87)$ & $(8.73)$ \\
Years in Business/at Job & $0.0701^{* *}$ & $0.0778^{* *}$ & $0.0653^{*}$ & $0.098^{* *}$ \\
& $(3.05)$ & $(17.48)$ & $(1.75)$ & $(10.15)$ \\
Years in Business/at Job ${ }^{2} / 100$ & $-0.3032^{* *}$ & $-0.4858^{* *}$ & $-0.337^{*}$ & $-0.7242^{* *}$ \\
& $(-2.04)$ & $(-13.85)$ & $(-1.74)$ & $(-8.09)$ \\
Years in Business/at Job ${ }^{3} / 1000$ & 0.034 & $0.0806^{* *}$ & 0.056 & $0.1388^{* *}$ \\
& $(1.27)$ & $(11.6)$ & $(1.48)$ & $(6.31)$ \\
Constant & $9.5505^{* *}$ & $9.6865^{* *}$ & $9.0906^{* *}$ & $9.256^{* *}$ \\
& $(75.73)$ & $(444.68)$ & $(44.79)$ & $(226.58)$ \\
R squared within & & & & 0.1002 \\
R squared between & 0.0180 & 0.0559 & 0.0380 & 0.1002 \\
R squared overall & 0.0784 & 0.2780 & 0.0933 & 0.0507 \\
Number of Observations & 0.0596 & 0.2039 & 0.0972 & 0.0722 \\
\hline
\end{tabular}

Note: t-statistics are shown in parentheses.

Table 11

Fixed Effects Log Annual Earnings Models, Women

\begin{tabular}{lcccc} 
& \multicolumn{2}{c}{ Native } & \multicolumn{2}{c}{ Immigrant } \\
& $\begin{array}{c}\text { Self } \\
\text { Employed }\end{array}$ & Wage/Salary & $\begin{array}{c}\text { Self } \\
\text { Employed }\end{array}$ & Wage Salary \\
\hline Typical Weekly Hours Worked & $0.0075^{* *}$ & $0.0091^{* *}$ & $0.0105^{* *}$ & $0.0105^{* *}$ \\
& $(3.34)$ & $(19.67)$ & $(3.57)$ & $(9.27)$ \\
Years in Business/at Job & $0.1146^{* *}$ & $0.1081^{* *}$ & $0.0713^{*}$ & $0.1151^{* *}$ \\
& $(2.52)$ & $(21.17)$ & $(1.74)$ & $(9.47)$ \\
Years in Business/at Job ${ }^{2} / 100$ & $-0.6583^{* *}$ & $-0.7356^{* *}$ & $-0.343^{*}$ & $-0.7831^{* *}$ \\
& $(-1.96)$ & $(-15.87)$ & $(-1.68)$ & $(-6.6)$ \\
Years in Business/at Job ${ }^{3} / 1000$ & 0.102 & $0.1274^{* *}$ & & $0.1348^{* *}$ \\
& $(1.45)$ & $(12.12)$ & & $(4.91)$ \\
Constant & $8.7411^{* *}$ & $9.0955^{* *}$ & $8.6986^{* *}$ & $8.7275^{* *}$ \\
& $(49.47)$ & $(397.64)$ & $(41.23)$ & $(165.91)$ \\
R squared within & & & & 0.1415 \\
R squared between & 0.0273 & 0.0932 & 0.0627 & 0.0918 \\
R squared overall & 0.1354 & 0.2711 & 0.0274 & 0.1217 \\
Number of Observations & 0.0940 & 0.2149 & 0.0378 & 0.1217 \\
\hline
\end{tabular}

Note: t-statistics are shown in parentheses. 


\section{Figures}

Figure 1

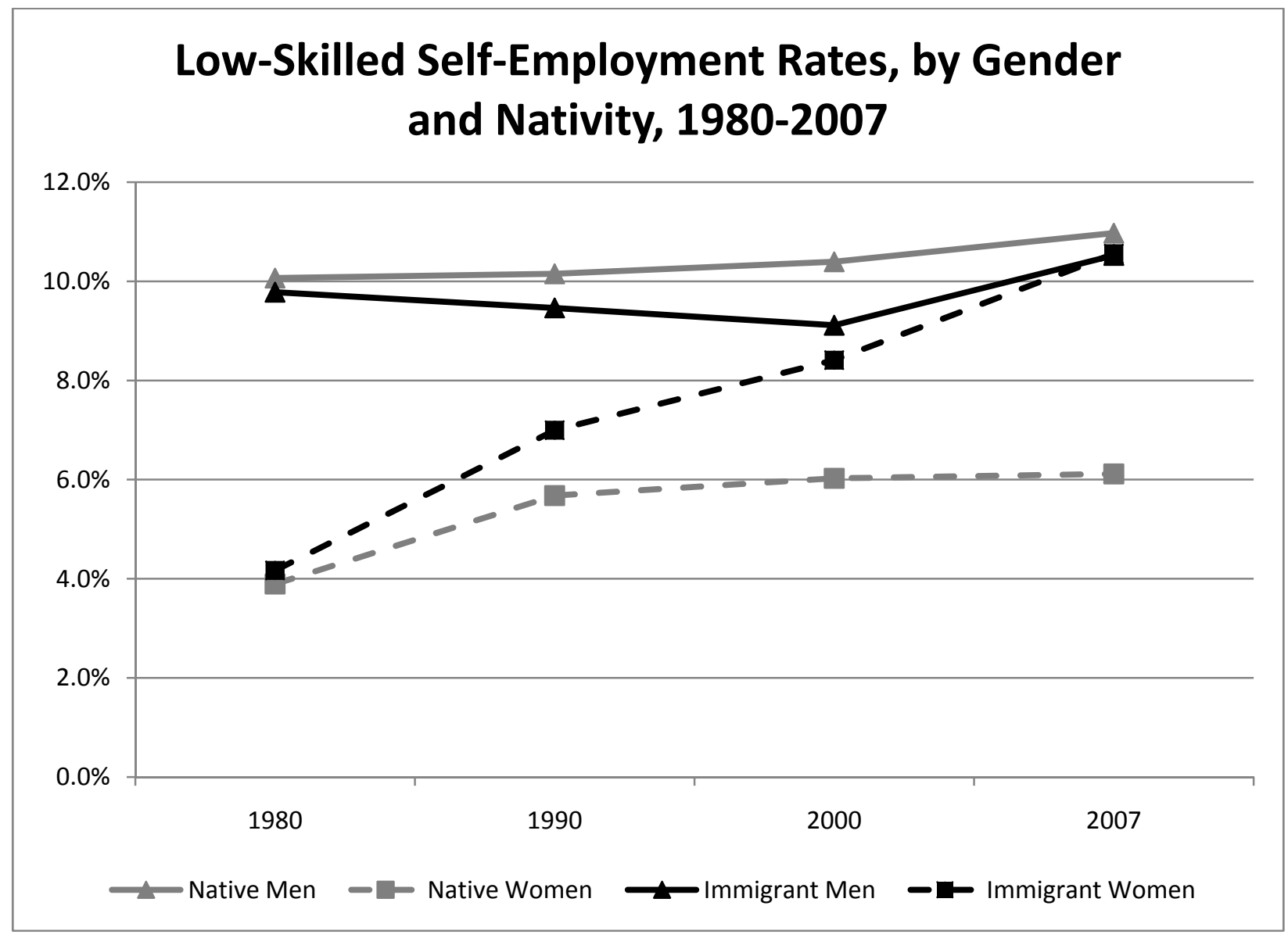

Source: 1980, 1990 and 2000 U.S. Census; 2005-2007 American Community Survey. 
Figure 2

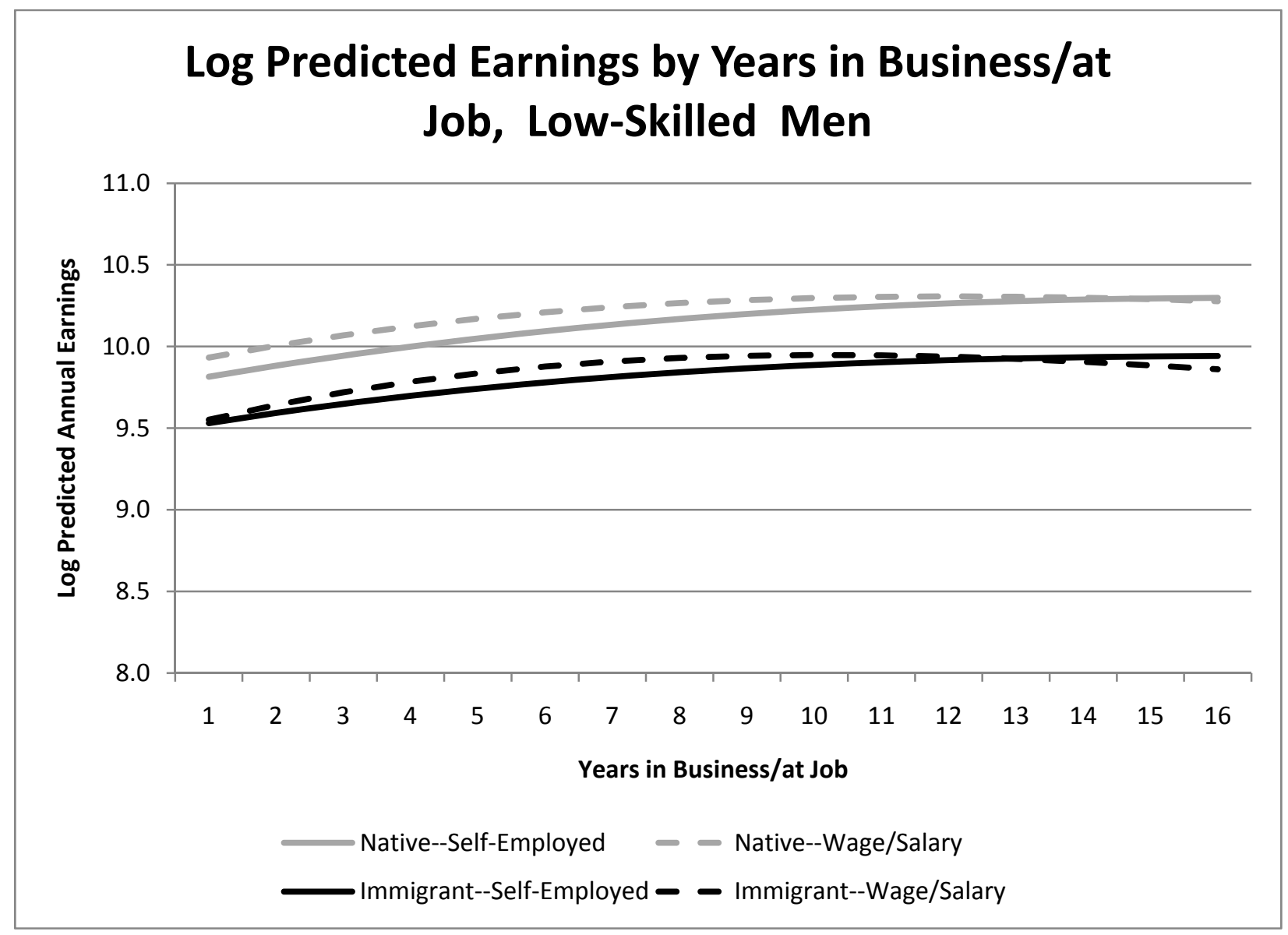

Note: The predicted log annual earnings are generated from the regression estimates presented in Table 10. 
Figure 3

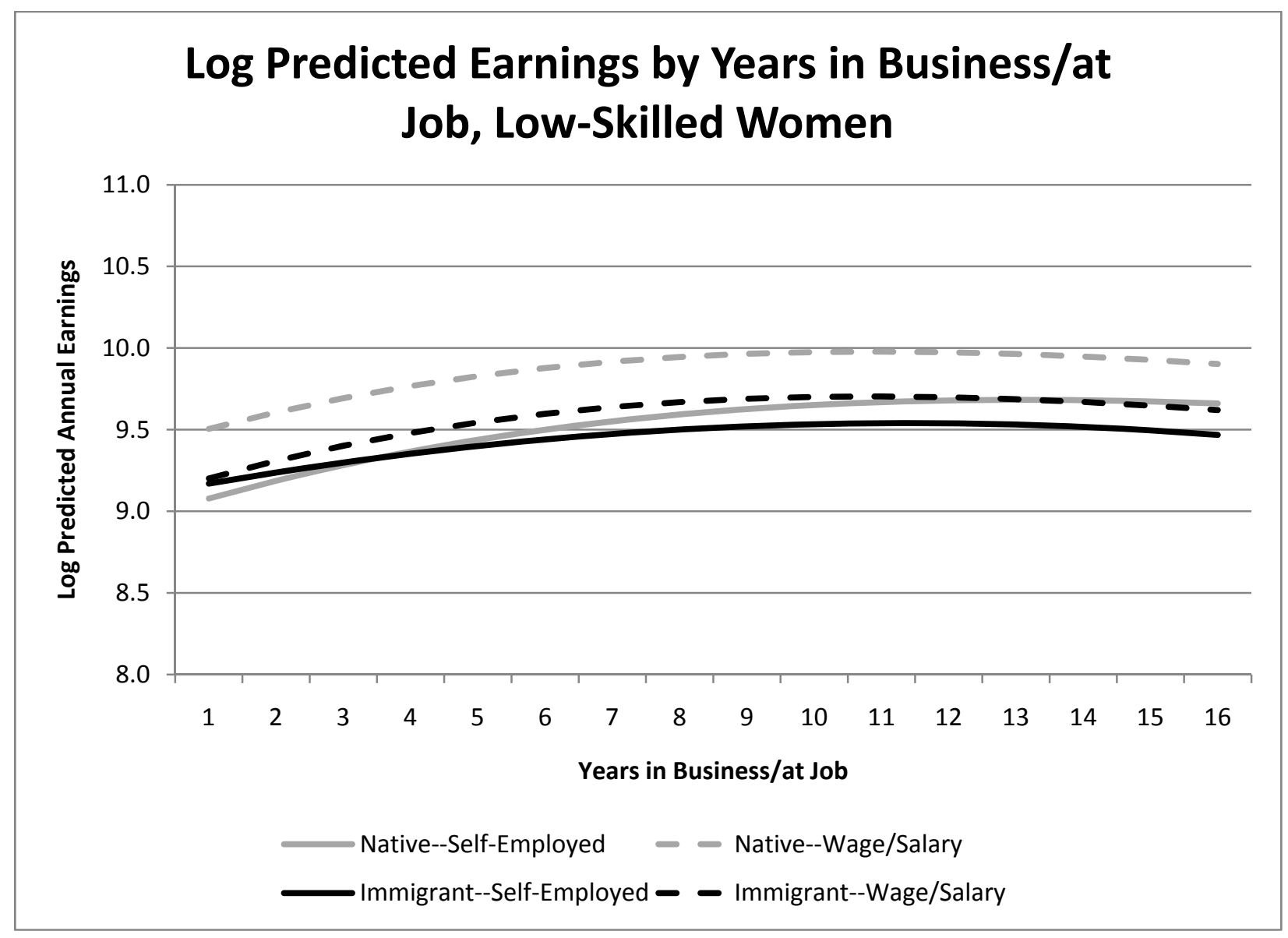

Note: The predicted log annual earnings are generated from the regression estimates presented in Table 11. 